\title{
İlk doz kolistin kullanımı sonrasında kolistine bağlı olarak nöropati gelişen bir olgu
}

\section{A case with neuropathy due to colistin after using first dose of colistin}

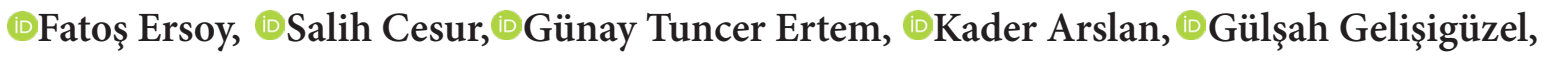 \\ ๑Çiğdem Ataman Hatipoğlu, @Sami Kınıklı \\ Sağlık Bilimleri Üniversitesi Ankara Eğitim ve Araştırma Hastanesi, Enfeksiyon Hastalıkları ve Klinik Mikrobiyoloji Kliniği, Ankara, Türkiye
}

Cite this article as / Bu makaleye atıf için: Ersoy F, Cesur S, Ertem GT, et al. İlk doz kolistin kullanımı sonrasında kolistine bağlı olarak nöropati gelişen bir olgu. J Med Palliat Care 2021; 2(1): 25-27.

\section{ÖZ}

Kolistin, çoğul ilaca dirençli Gram-negatif basillere bağlı enfeksiyonların tedavisinde yaygın olarak kullanılan bir antibiyotiktir. Kolistine bağlı olarak gelişen yan etkiler arasında nefropati ve nöropati yer alır. Kolistine bağlı olarak gelişen nörotoksisite; parestezi, baş dönmesi, görsel değişiklikler, ataksi ile nöromüsküler blokaj şeklinde ortaya çıkabilir. Bu yazıda dirençli Klebsiella pneumoniae’ya bağlı üriner sistem enfeksiyonu tanısıyla imipenem ve kolistin tedavisi başlanan 68 yaşında kadın hastada kolistin ilk dozunu takiben kolistine bağlı olarak dudaklarda ve parmaklarda parestezi gelişen ve tedavisi sonlandırılan bir olgu sunuldu. İlaç kesildikten sonra hastanın parestezisi düzeldi, hastanın tedavisine imipenem ve trimetoprim-sülfametoksazol kombinasyonu ile devam edildi. Sonuç olarak, kolistin tedavisi alan hastalar nöropati semptomları açısından yakından izlenmeli ve nörotoksisite gelişmesi durumunda ilaç tedavisi kesilmelidir.

Anahtar Kelimeler: Çoğul ilaca dirençli K. pneumoniae, kolistin, yan etki, nörotoksisite

\begin{abstract}
Colistin is an antibiotic commonly used in the treatment of infection due to multiple drug resistant Gram-negative bacilli. Colistin side effects include of nephropathy and neuropathy. Neurotoxicity due to colistin can be occur as paresthesia, dizziness, visual changes, and neuromuscular blockade with ataxia. In this article, a case of 68-year-old female patient with a diagnosis of urinary tract infection due to resistant Klebsiella pneumoniae and treatment of imipenem and colistin after the first dose of colistin and her treatment colistin was stoped upon the development of paresthesia in the lips and fingers. After discontinuation of the drug, the patient's paresthesia improved, and the treatment was continued with a combination of imipenem and trimethoprim-sulfamethoxazole. As a result, patients receiving colistin therapy should be closely monitored for symptoms of neuropathy and drug therapy should be discontinued if neurotoxicity develops.
\end{abstract}

Keywords: Multidrug resistance, Klebsiella pneumoniae, colistin, side effect, neurotoxicity

\section{GİRIŞ}

Hastane kaynaklıçoğul ilaca dirençli veya panrezistan Gramnegatif bakterilere bağlı enfeksiyonlar önemli bir mortalite ve morbidite nedenidir (1). Çoklu ilaca dirençli (ÇID) ve panrezistan Acinetobacter baumannii (A. baumannii), Pseudomonas aeruginosa (P. aeruginosa) ve Enterobactericea ailesi üyelerinin tedavisinde ilk tercih antibiyotik polimiksin grubunda yer alan kolistin veya polimiksin B'dir. Kolistin nefrotoksik ve nörotoksik bir antibiyotik olup hastaların bu yan etkiler açısndan yakından takip edilmesi gerekir (2).

$\mathrm{Bu}$ yazıda üriner sistem enfeksiyonu nedeniyle kliniğimize yatırılan ve idrar kültüründe ÇİD, kolistine duyarlı Klebsiella pneumoniae (K. pneumoniae) üremesi üzerine kolistin ve meropenem tedavisi başlanan, ilk doz kolistin tedavisini takiben nörotoksisite gelişen bir olgu sunularak literatür tartışılmıştır.

\section{OLGU}

Altmış sekiz yaşında kadın hasta halsizlik, iştahsızlık ve ani gelişen bayılma şikayetleri ile acil servise getirildi. Anamnezinden 2 ay önce dirençli K. pneumoniae ya bağlı üriner sistem enfeksiyonu tanısıyla enfeksiyon hastalıkları servisinde yattığ 1 öğrenildi. Öz geçmişinde hipertansiyon 
ve diabetes mellitusu mevcuttu. Acil serviste aldığ $1-$ çıkardığı sıvı takibi için sonda takılan hastanın alınan idrar örneğinde piyüri ve hematüri saptanması üzerine enfeksiyon hastalıkları kliniğine konsülte edildi.

Fizik muayenesinde ateş $37,4^{\circ} \mathrm{C}$, nabız $77 / \mathrm{dk}$, genel durumu iyi, bilinci açıktı. Laboratuvar testlerinde lökosit

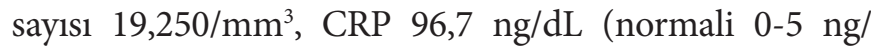
dL), eritrosit sedimentasyon hızı $84 \mathrm{~mm} /$ saat, serum kreatinin değeri $2,68 \mathrm{mg} / \mathrm{dL}$, diğer testleri normaldi. İdrar tetkikinde bol lökosit saptanması üzerine üriner sistem enfeksiyonu ön tanısıyla kliniğe yatırıldı. Kan ve idrar kültürleri alındıktan sonra hastaya ertapenem tedavisi başlandı. Yapılan üriner ultrasonografisinde sol böbrek alt pol kaliksi düzeyinde taş yönünden şüpheli milimetrik ekojenite izlendi, üriner bilgisayarlı tomografi (BT)'de ise sol böbrek alt polde $6 \mathrm{~mm}$ çapında taş dansitesi saptandı Ertapenem tedavisinin 8. gününde dizüri ve pollaküri şikeyetlerinin devam etmesi ve idrar inkontinansının olması üzerine alınan idrar kültüründe $105 \mathrm{cfu} / \mathrm{ml} \mathrm{K}$. pneumoniae ürediği rapor edildi. Üreyen etkenin VITEK 2 otomatize identifikasyon ve antimikrobiyal duyarlılık sistemiyle kolistin ve trimetoprim/sulfametoksazole duyarlı, meropeneme orta duyarlı, diğer antibiyotiklere ise dirençli olduğu raporlandı. Hastaya meropenem 3x1 gr intravenöz ve kolistin $300 \mathrm{mg}$ yükleme, ardından 2x150 mg dozda başlandı. Tedavinin ilk dozundan sonra parmaklarda ve ağız çevresinde uyuşma ve sıkıntı hissi tarifleyen hastada kolistine bağlı nörotoksisite düşünüldü. Kolistin tedavisi kesilerek, tedavisi meropenem ve trimetoprim/ sulfametoksazol olarak düzenlendi. Tedavinin 3.gününde alınan idrar kültüründe üreme olmadı, mevcut tedavisi 7 güne tamamlandı. Tedavi esnasında serum kreatinin değeri $2,1 \mathrm{mg} /$ dl'ye çıkan hasta nefroloji kliniğine danışlarak tedavisi düzenlendi. Genel durumu düzelen, serum kreatinin değeri $1,7 \mathrm{mg} /$ dL'ye ve CRP düzeyi 12,7 $\mathrm{mg} /$ Lye gerileyen hasta kontrole gelmek üzere taburcu edildi.

\section{TARTIŞMA}

Çoklu ilaca dirençli Gram-negatif bakterilerin neden olduğu enfeksiyonlar birçok antibiyotik sınıfına dirençli olduğu için tedavileri ve kontrolleri güçtür. Kolistin diğer adıyla polimiksin E, 1959'dan beri ÇİD Gramnegatif bakterilerin neden olduğu enfeksiyonları tedavisinde kullanılan eski bir antibiyotiktir. Kolistine bağlı nefrotoksisite ve nörotoksisite gibi istenmeyen yan etkilerin ortaya çıkması nedeniyle, bu antibiyotiğin kullanımına belirli bir süre ara verilmiş ancak daha sonra dirençli Gram-negatif bakteri enfeksiyonların tedavisinde başka tedavi seçeneklerinin olmaması nedeniyle tekrar kullanıma girmiştir (3-6).
Kolistin, günümüzde ÇİD Gram-negatif bakteri enfeksiyonların tedavisinde en sik kullanılan antibiyotiklerden biridir. Kolistin özellikle karbapeneme dirençli ÇİD $P$. aeruginosa, $A$. baumannii, K. pneumoniae, Escherichia coli neden olduğu enfeksiyonların tedavisinde yaygın olarak kullanılmaktadır. Kolistinin Gram-negatif bakterilere karşı etki mekanizması başlıca hedefi Gramnegatif bakterilerin dış membranında yer alan lipopolisakkarittir. Kolistin Gram-negatif bakterileirn hücre zarı sentezini inhibe ederek etkinlik gösteren polipeptid bir antibiyotiktir (3). Kolistine bağlı başlıca yan etkiler nefrotoksisite ve nörotoksisistedir. Kolistin tedavisi sırasında görülebilecek diğer yan etkiler; aşırı duyarlılık reaksiyonu, deri döküntüsü, ürtikeryal, kaşıntı, kas güçsüzlüğü ve hafif gastrointestinal yakınmalardır $(5,6)$.

Nörotoksisite yan etkisi, baş dönmesi, uyuşukluk, yüz ve periferik parestezi, vertigo, görme kaybı, ataksi, nöromüsküler blokaj şeklinde ortaya çıkabilir. Nöromüsküler blokaj solunum yetmezliğine veya apneye yol açabilir. Kolistin intraventriküler ve intratekal uygulaması, özellikle yüksek dozda, nöbete neden olabileceğinden yakından izlenmelidir (4). Birçok çalışmada, kistik fibrozlu hastalarda nörotoksik yan etkilerinin daha fazla olasılıkla ortaya çıktığı rapor edilmiștir). Kolistin tedavisi sırasında nörotoksisitenin ana semptomu olan parestezinin insidansının yaklaşı $\% 7$ olduğu bildirilmiştir (3). Nörotoksisite ve nefrotoksisite yan etkileri ilaç kesildiğinde geri dönüşümlüdür (3-6).

Kolistin kullanımı sırasında görülebilen nefrotoksisite ve nörotoksisite doza bağımlı ve geri dönüşlüdür (7). Yan etki ile karşılaşıldığı zaman başka bir alternatif antibiyotiğin kullanılabiliyorsa polimiksin tedavisinin kesilmesi önerilmektedir $(3,8,9)$. Kolistin nörotoksisitesine bağlı olarak parestezi, kas zayıflığı, perifik nöropati ve respiratuar paraliziye neden olan nöromüsküler blokaj görülebilmektedir (10).

Polimiksinlerin kullanımı sonucunda nörotoksisite görülme sıklığı, nefrotoksisite görülme sıklığına göre oldukça azdır $(3,10,11)$. Kolistine bağlı nörotoksisite gelişiminin, hastaya verilen toplam kümülatifkolistimetat sodyum dozuylailişkili olduğu saptanmıştır. Nörotoksisite riskini artıran durumlar arasında hipoalbüminemi ve eş zamanlı nonsteroidal antiinflamatuvar ilaç kullanımı yer almaktadır $(3,12)$. Nörotoksisite olarak en sık görülen parestezidir, bunun dişında baş dönmesi, bulantı ve kusma, görsel değişiklikler, ataksi ve nöromüsküler blokaj da görülebilir $(7,12)$. Diğer nörotoksik yan etkiler içerisinde nöbet gelişimi, aseptik menenjit, hipotoni, diyafram paralizisi ve kauda equina sendromu da bildirilmiştir $(13,14)$. 
Parestezi, intravenöz kolistimetat sodyum ile tedavi edilen hastaların yaklaşı \%27'sinde görülmektedir $(6,10)$. Kistik fibrozis hastalarında ise \%29'a varan nörolojik yan etki bildirilmiştir. Nörotoksisite genellikle polimiksin tedavisine başladıktan sonraki 5 gün içinde gelişmektedir (15).

Sunduğumuz olgu kolistin ilk dozundan sonra dudaklarda ve parmaklarda uyuşma, sıkıntı hissi şeklinde nörotoksisitenin ortaya çlkması nedeniyle ilginçtir.

Bulut ve ark. (11) ÇİD $K$. pneumoniae’ya bağlı üriner enfeksiyonu tanısıyla imipenem ve kolistin kombinasyonu başlanan 74 yaşında erkek hastada kolistine bağlı nörotoksisite sonucunda baş dönmesi, ağız ve baş çevresinde uyuşma ve sıkıntı hissi geliştiğini bildirmişlerdir. Olguda kolistin tedavisi kesildikten sonra nörotoksisite bulgularının tamamen düzeldiği bildirilmiştir. Sunduğumuz olguda da benzer şekilde idrar kültüründe çoğul ilaca dirençli $K$. pneumoniae üremesi üzerine kolistin ve meropenem kombinasyon tedavisi başlandi. Hastada ilk doz kolistin tedavisini takiben parmaklarda ve ağız çevresinde uyuşma ve sıkıntı hissi olması üzerine kolistin tedavisi kesildi. Sunduğumuz olguda kolistin nörotoksisitesini arttıran hipoalbüminemi ve nonsteroid antiinflamatuvar ilaç kullanımı yoktu. Reed ve ark. (16) kolistin kullanan kistik fibrozisli 31 hastada yaptıkları çalışmada hastaların 16'sında oral ve perioral parestezi, 5 hastada baş ağrisı, 5 hastada alt ekstremitelerde zayıflık geliștiği bildirilmiştir. $\mathrm{Bu}$ nörolojik yan etkiler ilacın kesilmesi ile düzelmiştir $(11,16)$.

\section{SONUÇ}

Sunduğumuz olguda olduğu gibi kolistin tedavisi başlanan hastalarda ilk dozu takiben nörotoksisite gelişebileceği akılda tutulmalı, nörotoksitite gelişmesi durumunda ilaç tedavisi kesilerek varsa alternatif ilaçlar kullanılmalıdır.

\section{ETIKK BEYANLAR}

Aydınlatılmış Onam: Bu çalışmaya katılan hastadan yazılı onam alınmıştır.

Hakem Değerlendirme Süreci: Harici çift kör hakem değerlendirmesi.

Çıkar Çatışması Durumu: Yazarlar bu çalışmada herhangi bir çıkara dayalı ilişki olmadığını beyan etmişlerdir.

Finansal Destek: Yazarlar bu çalışmada finansal destek almadıklarını beyan etmişlerdir.

Yazar Katkıları: Yazarların tümü; makalenin tasarımına, yürütülmesine, analizine katıldığını ve son sürümünü onayladıklarını beyan etmişlerdir.

\section{KAYNAKLAR}

1. Nørgaard SM, Jensen CS, Aalestrup J, Vandenbroucke-Grauls CMJE, de Boer MGJ, Pedersen AB. Choice of therapeutic interventions and outcomes for the treatment of infections caused by multidrug-resistant gram-negative pathogens: a systematic review. Antimicrob Resist Infect Control 2019; 8: 170.

2. Karaiskos I, Giamarellou H. Multidrug-resistant and extensively drug-resistant Gram-negative pathogens: current and emerging therapeutic approaches. Expert Opin Pharmacother 2014; 15: 1351-70.

3. Loho T, Dharmayanti A. Colistin: an antibiotic and its role in multiresistant Gram-negative infections. Acta Med Indones 2015; 47: 157-68.

4. Falagas ME, Kasiakou SK. Colistin: the revival of polymyxins for the management of multidrug-resistant gram-negative bacterial infections. Clin Infect Dis 2005; 40: 1333-41.

5. Tamma PD, Newland JG, Pannaraj PS, et al. The use of intravenous colistin among children in the United States: results from a multicenter, case series. Pediatr Infect Dis J 2013; 32: 17-22.

6. Ecemiș S. Yoğun bakım ünitelerinde kolistin kan düzeyi izlemi ve değerlendirilmesi. Yüksek Lisans Tezi. Ankara, 2019

7. Kelesidis T, Falagas ME. The safety of polymyxin antibiotics. Expert Opin Drug Saf 2015; 14: 1687-1701.

8. Pogue JM, Lee J, Marchaim D, et al. Incidence of and risk factors for colistin-associated nephrotoxicity in a large academic health system. Clin Infect Dis 2011; 53: 879-84.

9. Deryke CA, Crawford AJ, Uddin N, Wallace MR. Colistin dosing and nephrotoxicity in a large community teaching hospital. Antimicrob Agents Chemother. 2010; 54: 4503-5.

10. Falagas ME, Kasiakou SK. Toxicity of polymyxins: a systematic review of the evidence from old and recent studies. Crit Care 2006; 10: R27.

11.Bulut C, Yamazhan T, Işıkgöz M, Pullukçu H, Ulusoy S.İlk Doz kolistin tedavisini takiben gelişen toksisite: Kolistin ne kadar güvenli? ANKEM Derg 2016; 30: 57-61.

12.Duncan DA. Colistin toxicity. Neuromuscular and renal manifestations. Two cases treated by hemodialysis. Minn Med 1973; 56: 31-5.

13. Ng J, Gosbell IB, Kelly JA, Boyle MJ, Ferguson JK. Cure of multiresistant Acinetobacter baumannii central nervous system infections with intraventricular or intrathecal colistin: case series and literature review. J Antimicrob Chemother 2006; 58: 1078-81.

14. Velkov T, Dai C, Ciccotosto GD, Cappai R, Hoyer D, Li J. Polymyxins for CNS infections: Pharmacology and neurotoxicity. Pharmacol Ther 2018; 181: 85-90.

15. Koch-Weser J, Sidel VW, Federman EB, Kanarek P, Finer DC, Eaton AE. Adverse effects of sodium colistimethate. Manifestations and specific reaction rates during 317 courses of therapy. Ann Intern Med 1970; 72: 857-68.

16. Reed MD, Stern RC, O'Riordan MA, Blumer JL. The pharmacokinetics of colistin in patients with cystic fibrosis. J Clin Pharmacol 2001; 41: 645-654. 